\title{
Dimensi Kepercayaan dalam Usaha Pelepas Uang (Studi Kasus di Kabupaten Semarang)
}

\author{
Yustinus Wahyudi ${ }^{1}$, Gatot Sasongko ${ }^{2}$ \\ ${ }^{1}$ Fakultas Interdisiplin Magister Studi Pembangunan, Universitas Kristen Satya Wacana, Salatiga, 50711,. \\ ywahyudi2310@gmail.com \\ ${ }^{2}$ Universitas Kristen Satya Wacana, Salatiga, 50711,. gatot.sasongko@ @taff.uksw.edu
}

Diterima: 11 Desember 2018

Direview: 24 Juni 2019

Diterbitkan: 31 Juli 2019

Hak Cipta (C) 2019 oleh Penulis (dkk) dan Jurnal Sosial Humaniora (JSH)

*This work is licensed under the Creative Commons Attribution International License (CC BY 4.0).

http://creativecommons.org/licenses/by/4.0/ (c) (i) Open Access
Subject Areas: Social and Economics

\begin{abstract}
The informality of the money lender business is closely related to transaction costs and risks in carrying out its business. Trust is vital and plays an important role in the sustainability of money lender businesses. Trust serves to reduce transaction costs, mortgage loan risks and the determination of collateral. This study will look at the role of trust dimensions, namely ability, benevolence, and integrity in money lender loan transactions in Semarang Regency. To achieve this goal, the research uses a qualitative approach with case studies, which aims to comprehensively understand the role of the dimensions of trust in lending transactions in money lender businesses. Without business chains such as farmers and middlemen, fishermen and bosses as well as traders and moneylenders, the money-releasing business in Semarang Regency is able to develop trust with their customers. In addition, moneylenders provide loans for consumptive purposes.
\end{abstract}

Keywords: money lender; trust; ability; benevolence; integrity

\section{Pendahuluan/Latar Belakang}

Kepercayaan (trust) adalah salah satu dimensi yang ada di dalam modal sosial bersama norma dan jaringan sosial (Putnam, 1995). Fungsi kepercayaan adalah membentuk ikatan dalam sebuah hubungan atau relasi dalam jaringan. Relasi antar individu membutuhkan kepercayaan supaya menghasilkan hubungan kerjasama yang saling menguntungkan dan memungkinkan pencapaian tujuan.

Walaupun demikian, banyak diskusi tentang makna kepercayaan bersumber dari literatur yang berkaitan dengan organisasi dan analisis organisasi. Kepercayaan telah menarik minat psikolog, sosiolog, ekonom dan peneliti manajemen dan sebagai akibatnya muncul berbagai pendekatan dan definisi yang berbeda untuk memahami konsep kepercayaan. Apa yang terlihat dari banyak perbedaan definisi dan pendekatan untuk percaya adalah bahwa ada tema-tema kunci tertentu yang muncul dan tampak diakui sebagai bagian integral dari konsep kepercayaan, yaitu kepercayaan tergantung pada eksistensi risiko, kepercayaan bergantung pada interdependensi di antara para aktor; jika para pelaku tidak bergantung pada satu sama lain, tidak perlu ada kepercayaan, kepercayaan dikaitkan dengan kerentanan yaitu resiko dan saling ketergantungan menciptakan kerentanan, kepercayaan melibatkan harapan yang meyakinkan 
tentang perilaku masa depan; kepercayaan cenderung melekat pada sebagian besar hubungan; beberapa hubungan dapat dicirikan oleh kepastian kontrak.

Dalam upaya untuk membedakan kepercayaan dari aspek interaksi manusia lainnya, Mayer et al. (1995) mendefinisikan kepercayaan sebagai implikasi pengambilan risiko. Menjadi rentan terhadap tindakan orang lain adalah berada dalam kondisi keadaan berisiko dan kepercayaan membutuhkan kesediaan untuk menjadi rentan terhadap tindakan orang lain. Pengambilan risiko melekat dalam hubungan. Misalnya, dua individu dapat bekerja sama dalam upaya tanpa mempercayai satu sama lain. Namun kerja sama saja tidak naik ke tingkat kepercayaan. Atau, seseorang mungkin dapat memprediksi kinerja orang lain, tetapi itu tidak selalu berarti percaya juga. Demikian pula, keyakinan pada tindakan orang lain tidak sama dengan kepercayaan. Keyakinan dapat menyiratkan bahwa risiko kinerja bahkan tidak dipertimbangkan. Kepercayaan menyiratkan bahwa risiko kinerja melekat dalam keputusan untuk mempercayai yang lain. Atau, dinyatakan bahwa seseorang dapat sepenuhnya yakin bahwa orang lain tidak dapat dipercaya. Dalam mempercayai seseorang, pemberi kepercayaan mengharapkan seorang penerima kepercayaan untuk melakukan beberapa tindakan positif, mengakui mungkin ada risiko dan menerima bahwa risiko tidak dapat sepenuhnya dikurangi.

Kepercayaan telah menjadi topik penelitian dalam berbagai bidang, antara lain transaksi $E$ commerce (Wong (2017), Haryani, Nugroho, dan Adhipta (2015), Firdayanti (2012), Rofiq (2007), Listyorini (2015), Purwanto (2017), Yulianto (2014), Susanti dan Hadi (2013)), bisnis dan transaksi peminjaman melalui internet (Wahyu Sukmaningsih, 2018), kepemimpinan organisasi (Helmi dan Arisudana, 2009), kepercayaan konsumen dan loyalitas pelanggan (Cazier, 2007), sektor perbankan (Ennew (2007), Meilianasari (2012)), hubungan bisnis (Bartuševičienè dan Kazlauskienė, 2013), bidang pemasaran (Waluyani, 2010), dan transaksi keuangan (Bannink dan Wyman (2016), Moro, Kodwani, dan Lucas (2012)). Penelitian-penelitian tersebut menunjukkan bahwa kepercayaan memiliki bentuk peran tersendiri di berbagai bidang. Masih terbuka kemungkinan untuk melihat bagaimana peranan kepercayaan dikaji melalui dimensi-dimensi yang terkandung di dalam kepercayaan.

Kepercayaan dibentuk berdasarkan tiga dimensi yaitu kemampuan (ability), kebaikan hati (benevolence), dan integritas (integrity) penyedia layanan (Mayer et al., 1995). Seluruh dimensi ini menjadi unsur penting dalam membangun kepercayaan seseorang dalam proses mempercayai dan mengembangkan kepercayaan kepada suatu media, transaksi, atau komitmen tertentu. Masingmasing elemen, kemampuan, kebajikan, dan integritas ini, sangat penting untuk dipercaya. Masing-masing unik, dan tidak ada yang tidak dapat dikecualikan.

Penelitian dengan fokus tiga dimensi kepercayaan yaitu kemampuan (ability), kebaikan hati (benevolence), dan integritas (integrity) telah dilakukan oleh Wong (2017), Haryani, Nugroho, dan Adhipta (2015), Rofiq (2007), Listyorini (2015), Purwanto (2017), Yulianto (2014), Susanti dan Hadi (2013), Cazier (2007), Ennew (2007), Meilianasari (2012), Bartuševičienè dan Kazlauskienė (2013), Waluyani (2010), Bannink dan Wyman (2016), serta 
Moro, Kodwani, dan Lucas (2012). Penelitianpenelitian tersebut melihat peran dan pengaruh dimensi kepercayaan di dalam hubungan bisnis dan transaksi perdagangan, menggunakan pendekatan kuantitatif dan berada pada sisi permintaan atau konsumen. Masih terbuka untuk dilakukan penelitian dengan menggunakan dimensi kepercayaan pada hubungan bisnis terutama sisi suplai atau penawaran.

Pandangan tentang kepercayaan menunjukkan kesediaan individu untuk menerima kondisi kerentanan atas dasar harapan positif tentang niat atau perilaku orang lain dalam situasi yang dicirikan oleh interdependensi dan risiko. Perspektif yang ada tentang kepercayaan menunjukkan bahwa kesediaan untuk menjadi rentan dapat muncul dari perhitungan biaya dan manfaat, kecenderungan individu yang ada terhadap kepercayaan, pengetahuan dan pemahaman yang terperinci tentang mitra pertukaran dan atau keyakinan dalam sistem dan institusi sosial. Literatur mengenai kepercayaan mengindikasikan proses minimalisasi biaya transaksi. Sementara, literatur mengenai hubungan pinjam meminjam menunjuk kepada pentingnya sebuah hubungan terkait dengan minimalisasi resiko (moral hazard) dan meningkatkan ketersediaan pinjaman yang diberikan serta terkait dengan permintaan akan jaminan (colateral). Dengan demikian, peranan kepercayaan (trust) dalam hubungan pinjam meminjam berada dalam konteks minimalisasi biaya transaksi, minimalisasi resiko (moral hazard) dan kebutuhan jaminan (colateral) sebagai pendorong terselenggaranya proses transaksi peminjaman dana (Wiyani dan Prihantono, 2016). Sejauh ada kerentanan, risiko, dan interdependensi yang terkait dengan transaksi layanan keuangan, maka akan ada peran untuk kepercayaan.

Salah satu usaha terkait dengan transaksi peminjaman dana adalah usaha pelepas uang (money lender). Usaha pelepas uang merupakan jenis usaha yang serupa dengan lembaga keuangan bank dan lembaga keuangan non bank yang bergerak dalam jasa layanan keuangan dalam bentuk pinjaman. Perbedaannya terletak pada status usaha dimana bank dan lembaga keuangan non bank memiliki formalitas status usaha, sedangkan usaha pelepas uang merupakan usaha informal. Informalitas usaha pelepas uang membuat usaha ini memiliki karakteristik tertentu dalam proses transaksi peminjaman dana. Pinjaman yang diberikan melewati proses yang lebih mudah, lebih cepat dan fleksibel serta disesuaikan dengan resiko dan jaminan nasabah. Kepercayaan menjadi vital dan berperan penting dalam pelaksanaan kegiatan usaha serta keberlanjutan usaha pelepas uang.

Penelitian usaha pelepas uang menurut dimensi kepercayaan (trust) masih sangat terbatas. Sebagai bentuk usaha informal, usaha pelepas uang terkait erat dengan biaya transaksi dan resiko dalam pelaksanaan bisnisnya. Dengan demikian, peran dimensi kepercayaan dalam transaksi peminjaman dana pelepas uang dirasa perlu untuk diteliti lebih lanjut. Berdasarkan latar belakang tersebut, penelitian ini bertujuan melihat peranan dimensi kepercayaan (trust) yaitu dimensi kemampuan (ability), dimensi kebaikan hati (benevolence), dan dimensi integritas (integrity) pada transaksi peminjaman dana pelepas uang di Kabupaten Semarang. 


\section{Metode Penelitian}

Penelitian ini menggunakan metode kualitatif dengan pendekatan studi kasus. Pendekatan studi kasus dipilih untuk memahami fenomena keberadaan pelepas uang. Penelitian ini menggali informasi tentang usaha pelepas uang langsung dari para pelakunya. Fokus akan diarahkan kepada pelepas uang untuk mencari informasi tentang peranan dimensi kepercayaan. Langkah awal adalah penyusunan pedoman pertanyaan yang menghasilkan guideline penelitian sebagai panduan dalam melakukan wawancara di lapangan.

Langkah selanjutnya adalah penentuan informan kunci untuk membantu peneliti "masuk" ke dalam budaya yang asing dan kurang dikenal oleh peneliti. Informan kunci memiliki pengetahuan khusus, status dan keterampilan tertentu yang diketahui (Manzilati, 2017). Objek penelitian ini adalah pengusaha pelepas uang yang membangun bisnisnya di wilayah Kabupaten Semarang yaitu pengusaha pelepas uang selaku key-informan yang sudah dan telah melakukan usaha di wilayah Kabupaten Semarang. Kriteria usaha pelepas uang yang dipilih sebagai key-informan adalah pengusaha pelepas uang yang sudah lama terjun dalam bisnis tersebut (minimal dua tahun sudah berbisnis) dan kegiatan pelepas uang merupakan usaha utama yang dijalankan, bukan aktivitas sampingan.

Pengumpulan data menghasilkan data primer berupa transkrip wawancara, dokumentasi dan hasil penelitian. Dalam proses pengumpulan data, kegiatan wawancara mendalam menjadi penting karena wawancara ini memungkinkan pihak yang diteliti untuk memberikan gambaran dan definisi tentang dirinya sendiri dan lingkungannya serta tidak sekadar menjawab pertanyaan yang diajukan peneliti. Metode wawancara dilakukan secara informal dengan tetap berpegang pada pedoman wawancara yang telah dibuat. Hubungan baik antara peneliti dengan informan merupakan kunci penting keberhasilan mendapatkan informasi berharga dalam penelitian.

Peneliti juga melakukan wawancara tidak terstruktur yang diharap juga mampu menambah dan memperkaya data dari penelitian ini. Seluruh proses wawancara ini sudah terkonsep dalam sebuah interview guide dan dapat dibantu oleh alat rekam suara, serta mengandalkan ingatan dan catatancatatan kecil yang tidak banyak membuat kecurigaan dan ketidaknyamanan dari narasumber.

Untuk mencapai validitas data, triangulasi data perlu dilakukan. Triangulasi data merupakan teknik pemeriksaan keabsahan data yang memanfaatkan sesuatu yang lain diluar data itu untuk mengecek atau membandingkan data tersebut (Moleong, 2006). Setelah data diperoleh, langkah selanjutnya adalah melakukan penilaian data dan menganalisisnya. Analisis data ini bertujuan untuk memfokuskan penelitian sehingga meminimalisasi terjadinya pembiasan atau pembahasan yang meluas. Langkah-langkahnya adalah dengan membuat transkrip wawancara dan observasi yang telah dilakukan lalu peneliti mengkategorisasikan temuan-temuannya dari wawancara tersebut untuk disesuaikan dengan pertanyaan dan tujuan penelitian.

\section{Hasil Penelitian dan Pembahasan}

Usaha pelepas uang adalah transaksi keuangan di mana A meminjamkan ke B sejumlah uang untuk jangka waktu tertentu dengan perjanjian bahwa itu akan dikembalikan dengan bunga. Praktik ini memungkinkan pihak yang tidak memiliki uang dan pihak yang memiliki uang untuk dapat saling 
melakukan transaksi saling menguntungkan. Peminjam dapat menggunakan uang dengan imbalan membayar bunga yang disepakati kepada pemberi pinjaman selain jumlah pokok pinjaman. Kedua belah pihak mendapatkan manfaat dari pertukaran semacam itu; pihak peminjam mendapatkan manfaat penggunaan dana sementara pihak pemberi pinjaman mendapatkan manfaat berupa bunga pinjaman.

Penolakan terhadap usaha pelepas uang berasal dari dua sumber yang saling terkait: pandangan ekonomi tertentu dan pandangan etis tertentu. Secara ekonomi, usaha pelepas uang dianggap tidak produktif, seperti mengambil sesuatu tanpa imbalan. Secara etis, praktik itu dikutuk sebagai tidak bermoral, sebagai tidak adil, eksploitatif, egois dan melawan hukum alkitabiah. Usaha pelepas uang baik praktis maupun moral akan terus dikutuk sebagai penjahat ketimbang digembargemborkan sebagai pahlawan pada kenyataannya.

Pengetahuan ekonomi diperlukan untuk membantu menjelaskan usaha pelepas uang; mencakup pemahaman tentang mengapa pemberi pinjaman membebankan bunga pada uang dan mengapa mereka melakukan usaha tersebut. Pemberi pinjaman mengenakan bunga karena mereka memiliki kegunaan alternatif untuk sementara waktu dengan meminjamkan uang kepada peminjam. Ketika seorang pemberi pinjaman meminjamkan uang, dia tidak dapat menggunakan uang itu untuk beberapa keuntungan atau keuntungan untuk dirinya sendiri. Seandainya dia tidak meminjamkannya, dia bisa membelanjakannya untuk membeli barang-barang atau jasa yang akan dia nikmati atau dia dapat menginvestasikannya dalam usaha menghasilkan pendapatan lainnya.
Semakin lama jangka waktu pinjaman, semakin lama pemberi pinjaman harus menunda penggunaan alternatifnya dari uang itu. Jadi bunga dikenakan karena pemberi pinjaman memandang pinjaman sebagai penggunaan uang yang lebih baik dan lebih menguntungkan selama periode pinjaman daripada penggunaan alternatifnya dari dana yang sama pada waktu yang sama. Pengusaha pelepas uang menganggap bahwa manfaat meminjamkan dana lebih besar daripada alternatif penggunaan lain dari uangnya.

Pemberi pinjaman mencoba menghitung di awal kemungkinan bahwa semua modal pinjaman akan dibayar kembali beserta bunganya. Semakin tidak yakin pinjaman akan dibayar, semakin tinggi tingkat bunga yang akan dikenakan atau pinjaman tidak diberikan. Tingkat bunga yang lebih tinggi memungkinkan pemberi pinjaman untuk mendapatkan keuntungan karena kesediaan mereka untuk mengambil risiko yang lebih besar.

Prinsip ekonomi lain yang penting adalah bahwa peminjaman uang itu produktif. Dengan memilih kepada siapa ia akan meminjamkan uang, si pemberi pinjaman menentukan proyek mana yang akan ia bantu wujudkan dan individu mana yang akan ia berikan dengan peluang untuk meningkatkan kualitas hidup mereka dan hidupnya. Pemberi pinjaman menghasilkan pendapatan dengan memberi imbalan kepada orang-orang untuk kebaikan inovasi, produktivitas dan bakat kewirausahaan, sehingga meminimalkan kerugian dari orang-orang yang menunjukkan tanda-tanda stagnasi, kemalasan, tidak bertanggung jawab dan inefisiensi. Dalam mencari keuntungan, pemberi pinjaman tidak mempertimbangkan kesejahteraan masyarakat atau peminjam. Sebaliknya, ia menilai 
mengevaluasi risiko dan mencari manfaat terbesar atas tindakan ekonomi yang dilakukan. Dan, tentu saja, meminjamkan uang tidak "mandul"; itu berbuah: Ini memungkinkan peminjam untuk memperbaiki kehidupan mereka atau menghasilkan barang atau jasa baru. Baik peminjam maupun pemberi pinjaman mendapat manfaat dari pertukaran. Pemberi pinjaman mendapatkan untung dan peminjam dapat menggunakan modal baik untuk konsumsi atau tujuan investasi lainnya.

\section{Pinjaman dengan jaminan kartu ATM}

Kemampuan mengacu pada keterampilan, kompetensi, dan karakteristik yang memungkinkan seseorang untuk melakukan beberapa domain tugas tertentu. Elemen ini menyiratkan bahwa kepercayaan dapat menjadi domain khusus. Artinya, seseorang dapat percaya kepada orang lain dalam situasi tertentu tetapi tidak mempercayai orang lain dalam situasi berbeda. Perbedaan-perbedaan spesifik situasional dalam kepercayaan ini tidak mencerminkan kualitas hubungan, tetapi fakta bahwa seseorang mungkin memiliki kemampuan yang tinggi dalam tugas-tugas tertentu tetapi kekurangan kemampuan dalam tugas yang lain. Dalam hal membangun kepercayaan, mengidentifikasi kemampuan sebagai elemen kunci dari kepercayaan menyiratkan bahwa seseorang harus terlebih dahulu meyakinkan orang lain tentang kemampuan mereka sebelum mereka berharap untuk dipercaya.

Kemampuan (ability) adalah kapasitas individu untuk mengerjakan berbagai tugas dalam suatu pekerjaan. Dalam hal ini, terkait bagaimana pengusaha pelepas uang mampu meyakinkan calon nasabah dan memberikan jaminan atas kepuasan dan keamanan ketika melakukan transaksi peminjaman dana. Kemampuan dipengaruhi oleh pengetahuan (knowledge), keterampilan (skill), dan sikap (attitude). Artinya, bagaimana pengusaha pelepas uang memiliki pengetahuan tentang usaha peminjaman uang, bagaimana ketrampilan mengelola pinjaman kepada nasabah dan sikap terkait dengan proses penyelesaian pinjaman nasabah serta pengalaman masa lalu dalam usaha peminjaman dana.

Kemampuan (ability) dari pelepas uang adalah kompetensi dan karakteristik dalam menyediakan proses transaksi pinjam meminjam dan bagaimana pelepas uang mampu meyakinkan nasabah dan memberikan jaminan atas kepuasan dan keamanan nasabah dalam transaksi peminjaman dana. Kemampuan meliputi pengetahuan, ketrampilan, sikap dan pengalaman usaha pelepas uang dalam menjalankan usahanya.

Pelepas uang memiliki kemampuan untuk menyediakan transaksi peminjaman dana yang berkualitas bagi nasabah. Pelepas uang di Kabupaten Semarang menyediakan berbagai layanan transaksi peminjaman dana bagi nasabahnya. Pilihan layanan transaksi disesuaikan dengan kebutuhan calon nasabah. Ragam transaksi yang ada meliputi peminjaman dana berdasarkan jaminan yang diajukan, yaitu memegang kartu ATM, pinjaman berdasarkan jaminan benda tidak bergerak seperti perhiasan, sertifikat tanah dan barang elektronik serta pinjaman berdasarkan jaminan kendaraan bermotor. Jangka waktu peminjaman dana pun diserahkan kepada calon nasabah, apakah jangka pendek; berkisar antara 1-2 bulan, atau jangka panjang; berkisar antara 4-6 bulan. 
Pelepas uang memiliki pengalaman sehingga mampu melakukan proses transaksi tepat pada waktunya. Usaha yang telah digeluti sejak tahun 2011 membuat pelepas uang (Ibu T) memiliki banyak pengalaman menangani transaksi peminjaman dana. Tidak semua transaksi berjalan mulus dan lancar. Ada beberapa peristiwa yang dijadikan pengalaman penting dalam melayani nasabah. Misalkan: Ibu T tidak mau lagi melayani permintaan peminjaman dana dari calon nasabah berlatar belakang karyawan perusahaan garment atau tekstil. Hal ini dikarenakan sering terjadi kemacetan dalam proses pelunasan pinjaman atau istilah yang sering digunakan adalah "blong" atau "zonk". Meskipun telah ada jaminan berupa kartu ATM atau kendaraan bermotor, namun pelunasan pinjaman nasabah tidak ditepati. Bahkan, ada beberapa nasabah yang melarikan diri tanpa melunasi pinjaman yang sudah dilakukan. Salah satu faktor penyebabnya adalah tingginya turn-over di perusahaan garment dan tekstil. Nasabah yang melarikan diri telah berpindah tempat kerja dan sulit untuk ditelusuri untuk dilakukan penagihan.

Pelepas uang memiliki kemampuan yang baik dalam mengamankan transaksi. Terkait dengan pengamanan transaksi peminjaman dana, pelepas uang memiliki beberapa strategi agar transaksi bisa dilakukan dengan lancar dan pinjaman dapat dikembalikan beserta bunganya. Untuk calon nasabah berlatar belakang pekerja pabrik, pelepas uang lebih selektif dalam melayani permintaan peminjaman dana. Biasanya permohonan pengajuan pinjaman dana lebih diarahkan kepada pekerja tetap di beberapa perusahaan di wilayah Ungaran. Alasannya adalah pekerja tetap memiliki kecenderungan yang kecil untuk berpindah tempat kerja. Pinjaman ini dilakukan berdasarkan jaminan kartu ATM. Prosesnya adalah kartu ATM nasabah dipegang oleh pelepas uang sedangkan nomor PIN tetap dimiliki oleh nasabah. Saat gaji nasabah sudah dibayarkan perusahaan, pelepas uang bersama nasabah menuju ATM untuk melakukan pembayaran pinjaman.

Eksistensi usaha pelepas uang telah diakui pihak-pihak lain, seperti pelepas uang yang lain, nasabah yang pernah meminjam dan sebagainya. Pengakuan eksistensi usaha pelepas uang didasarkan pada dikenalnya pelepas uang diantara pengusaha pelepas uang yang lain dan nasabah yang pernah meminjam. Hal ini membuat calon nasabah yang ingin mengajukan pinjaman mendapatkan informasi secara "gethok tular". Informasi yang beredar juga membantu meningkatkan promosi usaha pelepas uang sehingga nasabah yang dilayani bertambah jumlahnya. Saat ini ada sekitar 28 nasabah dengan pinjaman menggunakan kartu ATM, 5 nasabah dengan jaminan perhiasan, 3 nasabah dengan jaminan laptop dan 10 nasabah yang menjaminkan kendaraan bermotor.

Pelepas uang memberikan layanan dengan fleksibilitas waktu dan tempat transaksi. Proses transaksi peminjaman dana dapat dilakukan dengan waktu yang fleksibel. Calon nasabah tinggal menghubungi pelepas uang untuk membuat janji bertemu di hari apapun sesuai kebutuhan. Biasanya waktu yang digunakan adalah siang hari dan malam sebelum istirahat. Pelepas uang pun melayani transaksi di rumah atau di tempat lain yang sudah disepakati.

Temuan ini sesuai dengan penelitian yang telah dilakukan Haryani et al. (2015), Ennew (2007), Listyorini (2015), Purwanto (2017), Wong 
(2017), Helmi dan Arisudana (2009) dan Rofiq (2007) bahwa kemampuan, kapasitas dan kompetensi di dalam dimensi kemampuan berperan dalam kepercayaan sebuah hubungan. Perbedaan dengan penelitian ini adalah penelitian Haryani et al. (2015), Ennew (2007), Listyorini (2015), Purwanto (2017), Wong (2017), Helmi dan Arisudana (2009) dan Rofiq (2007) berada pada sisi permintaan (konsumen) sementara penelitian ini fokus pada sisi penawaran (suplai) yaitu usaha pelepas uang. Lebih jauh, pendekatan dalam penelitian Haryani et al., (2015), Ennew (2007), Listyorini (2015), Purwanto (2017), Wong (2017), Helmi dan Arisudana (2009) menggunakan pendekatan kuantitatif sementara pendekatan penelitian ini menggunakan pendekatan kualitatif melalui studi kasus.

Lebih jauh, kepercayaan yang berkembang dalam transaksi usaha pelepas uang di Kabupaten Semarang serupa dengan usaha sejenis seperti rentenir di pasar tradisional atau usaha lain seperti ijon dan tengkulak di daerah pesisir. Kepercayaan tersebut didasarkan kepada hubungan atau relasi yang terjalin dengan calon nasabah, baik nasabah pedagang pasar, petani maupun nelayan. Walaupun demikian, hubungan atau relasi tersebut tetap memerlukan perekat agar satu sama lainnya tetap saling percaya (Hamka dan Danarti, 2010; Syafrini, 2014). Perekat yang dimaksud adalah kapasitas nasabah berdasarkan mata pencaharian, bisa berupa usaha (warung, toko, kios) pada pedagang pasar atau peralatan melaut (jaring, mesin tempel, peti es, perahu) pada nelayan. Keberadaan sebagai pedagang atau nelayan itulah yang memungkinkan nasabah memiliki sumber penghasilan untuk mengembalikan pinjaman.
Penelitian ini menemukan bahwa usaha pelepas uang di Kabupaten Semarang mengembangkan kepercayaan dengan cara yang berbeda, yaitu menggunakan jaminan kartu ATM. Usaha sejenis seperti rentenir, tengkulak, juragan atau ijon, menggunakan rantai usaha dan sumber penghasilan sebagai pertimbangan dalam pemberian pinjaman karena nasabahnya (petani, pedagang atau nelayan) tidak memiliki jaminan. Lebih jauh, pemberian pinjaman oleh pelepas uang di Kabupaten Semarang tidak didasarkan kepada tujuan menambah modal usaha untuk kegiatan produktif seperti bertani, melaut atau berdagang. Pemberian pinjaman ditujukan untuk tujuan konsumtif atau karena kebutuhan mendesak dan mendadak.

\section{Pinjaman tanpa jaminan dan toleransi pembayaran}

Kebajikan mengacu pada keinginan untuk membantu selain dari motif keuntungan. Elemen ini menyiratkan bahwa orang yang dipercaya memiliki beberapa keterikatan yang mendasarinya dengan si pemberi kepercayaan. Kebajikan tidak perlu memberikan sesuatu secara gratis, tetapi hal itu memerlukan perhatian lebih dari jumlah uang, kekuasaan, atau aset lain. Dalam hal membangun kepercayaan, mengidentifikasi kebajikan sebagai elemen kunci menyiratkan bahwa seseorang harus benar-benar peduli tentang hasil yang lain, peduli terhadap situasi yang dialami oleh orang lain serta memahami kepentingan orang lain. Kebajikan menyiratkan bahwa trustor memberi kepercayaan kepada trustee untuk berbuat sesuatu yang baik secara sukarela. Pemberian kepercayaan ini didasarkan pada ekspektasi trustor bahwa pinjaman 
yang telah diberikan akan dikembalikan beserta dengan pembayaran bunganya.

Kebajikan (benevolence) adalah keinginan baik pelepas uang dalam memberikan kepuasan transaksi dan bertanggung jawab atas kesejahteraan nasabah. Kebajikan mencakup perhatian, kesejahteraan dan dapat diharapkan. Pelepas uang memiliki perhatian ketika memberikan pelayanan bagi nasabahnya, memiliki kemauan untuk memberikan keuntungan bagi nasabahnya, memiliki itikad baik untuk memberikan kepuasan kepada nasabahnya serta memahami apa yang nasabah inginkan. Kebaikan hati merupakan kemauan penyedia usaha pelepas uang dalam memberikan manfaat yang saling menguntungkan antara dirinya dengan nasabah. Penyedia usaha pelepas uang selain mengejar keuntungan juga berusaha memberikan layanan yang maksimal kepada nasabahnya, sehingga pemenuhan kebutuhan terhadap kepuasan pengguna dapat tercapai dengan baik.

Contohnya apabila ada pengajuan pinjaman tanpa jaminan kepada pelepas uang. Transaksi ini dapat dilakukan hanya sewaktu-waktu dan bukan kondisi pada umumnya. Pinjaman tanpa jaminan dapat dilakukan pelepas uang hanya kepada saudara atau orang yang sudah dikenal dengan baik. Pelepas uang menunjukkan kebajikan dengan mengutamakan kepentingan orang lain dibandingkan motif keuntungan bisnisnya. Alasan pemberian pinjaman ini semata-mata dengan niat membantu dan mengutamakan nurani karena ada yang membutuhkan. Walaupun tanpa jaminan, pinjaman yang diberikan juga dikenakan bunga atau istilahnya adalah " $\mathrm{R}$ " kepada pokok pinjaman.
Kebajikan lainnya ditunjukkan lewat toleransi penagihan pinjaman yang sudah jatuh tempo. Pelepas uang memberikan toleransi kepada nasabah terkait dengan penyelesaian pinjaman yang sudah jatuh tempo. Contohnya pelepas uang memberikan toleransi keterlambatan pembayaran " $R$ " dalam waktu beberapa hari. Proses pemberian kelonggaran disertai dengan komunikasi yang intens dengan nasabah untuk menanyakan proses pembayaran pinjaman. Komunikasi yang dilakukan berupa pesan singkat, menelpon nasabah hingga berkunjung ke rumah nasabah. Beberapa alasan penundaan pembayaran dapat dimaklumi oleh pelepas uang sembari mengingatkan nasabah agar “sportif” dalam melakukan tanggung jawabnya.

Kebajikan (benevolence) terlihat dari pelepas uang yang tidak hanya mengejar keuntugan pribadi semata. Ada beberapa hal yang dikecualikan dalam pelaksanaan transaksi peminjaman dana, seperti tanpa jaminan dan pemberian toleransi keterlambatan pembayaran. Temuan ini sejalan dengan penelitian Ennew (2007), Cazier (2007), Kazlauskienè dan Bartuševičienė (2013), dan Waluyani (2010) bahwa kebajikan (benevolence) berperan dalam menumbuhkan kepercayaan. Sementara dalam penelitian Wong (2017), Haryani et al. (2015), Rofiq (2007), Listyorini (2015), dan Purwanto (2017) menemukan bahwa kebajikan (benevolence) tidak memiliki pengaruh terhadap kepercayaan.

\section{Langganan, reputasi dan prinsip sportif}

Integritas mengacu pada kepatuhan terhadap seperangkat prinsip yang dipercaya oleh pemberi kepercayaan. Integritas menyiratkan bahwa tindakan akan diambil dari seperangkat prinsip dan 
dievaluasi. Tindakan yang bertentangan dengan prinsip-prinsip tidak akan diambil. Mereka yang sejalan dengan prinsip-prinsip trustor dapat diberikan kepercayaan. Persepsi integritas memungkinkan trustor percaya bahwa tindakan akan diambil tanpa pemantauan atau paksaan. Dalam hal membangun kepercayaan, mengidentifikasi integritas sebagai elemen kunci menyiratkan bahwa seseorang harus memegang dan mengkomunikasikan prinsip mereka.

Integritas tidak terkait dengan ketrampilan atau kompetensi tertentu atau suatu hubungan relasi tertentu. Integritas merupakan bagian intrinsik dari komitmen seseorang berdasarkan prinsip moral sehingga integritas menjadi karakteristik personal seseorang. Dalam usaha peminjaman uang, integritas dapat membantu mengurangi moral hazard dan membantu meningkatkan reliabilitas informasi yang disampaikan oleh nasabah. Integritas meliputi pemenuhan informasi, kejujuran dan kehandalan. Pelepas uang akan memenuhi apa yang diharapkan oleh pelanggannya. Pelepas uang tidak akan menyembunyikan informasi yang penting bagi nasabahnya. Pelepas uang akan selalu menjaga reputasinya.

Integritas berkaitan dengan bagaimana perilaku atau kebiasaan penyedia usaha pelepas uang dalam menjalankan bisnisnya. Pemberian informasi kepada nasabah apakah sudah benar sesuai dengan perjanjian, aturan atau tidak. Sebagai landasan utama dalam membangun komunikasi yang efektif, integritas menjadi patokan apakah seseorang layak dipercaya atau tidak. Hubungan tidak akan terbangun tanpa adanya kepercayaan, sementara kepercayaan dihasilkan dari proses saling menghargai dan komunikasi dengan orang lain.
Kegagalan membangun komunikasi yang efektif berdampak pada tingkat keberhasilan suatu hubungan (Bhawika, 2017). Kepercayaan pada usaha pelepas uang dapat menghasilkan suatu sikap yang baik dari nasabah dan memungkinkan penurunan persepsi resiko.

Pelepas uang memiliki prinsip-prinsip dalam menjalankan bisnisnya. Prinsip ini melandasi proses transaksi peminjaman dana kepada nasabah. Prinsip yang utama adalah sportif. Apabila sudah berjanji maka harus ditepati. Apabila sudah sepakat mengenai peminjaman dana, maka pelepas uang akan sportif terkait dengan besaran bunga pinjaman dan ketentuan terkait dengan jaminan. Artinya, bunga pinjaman tidak akan berubah-ubah, sesuai dengan kesepakatan awal. Jatuh tempo pembayaran pinjaman selalu dicatat dalam buku transaksi sehingga penagihan dilakukan sesuai dengan jatuh tempo pembayaran. Jaminan milik nasabah pun tidak akan dijual, dieksekusi atau dilepas tanpa ada informasi kepada nasabah. Harapannya adalah nasabah juga melakukan tanggung jawab pembayaran pinjaman dengan lancar.

Lebih jauh, reputasi usaha selalu dijaga oleh pelepas uang. Hal ini dikarenakan pelepas uang menyadari bahwa kelangsungan usaha yang dilakukan terkait erat dengan reputasi yang dikenal. Apabila pelepas uang memiliki reputasi jelek di mata nasabah maupun pelepas uang yang lain, maka usahanya tidak akan terus berjalan, nasabahnya akan berpindah dan tidak akan mendapatkan calon nasabah yang baru. Dengan demikian, reputasi usaha berperan dalam integritas pelepas uang melalui. Temuan penelitian ini sejalan dengan penelitian Wong (2017), Haryani et al. (2015), Firdayanti (2012), Ennew (2007), Rofiq (2007), 
Kazlauskienè dan Bartuševičienė (2013), dan Waluyani (2010) yang menunjukkan bahwa dimensi integritas berperan dalam kepercayaan. Integritas berperan dalam proses kepercayaan melalui prinsip sportif, reputasi yang dikenal, keterbukaan informasi dalam sebuah hubungan sehingga mengurangi persepsi resiko yang mungkin terjadi.

\section{Kesimpulan}

Dalam konteks pelepas uang di Kabupaten Semarang, usaha pelepas uang memiliki cara yang unik dalam mengembangkan kepercayaan dan membuat pelepas uang percaya kepada nasabahnya. Dimensi kepercayaan dalam kemampuan (ability), kebaikan hati (benevolence), dan integritas (integrity) memiliki peranan dalam usaha pelepas uang, khususnya dalam transaksi peminjaman dana. Tanpa adanya rantai usaha seperti petani dan tengkulak, nelayan dan juragan maupun pedagang dan rentenir, usaha pelepas uang di Kabupaten Semarang mampu mengembangkan kepercayaan dengan nasabahnya lewat jaminan dan hubungan yang baik. Selain itu, pelepas uang juga memberikan pinjaman untuk tujuan konsumtif.

\section{Daftar Pustaka}

Bannink, A., \& Wyman, O. (2016). TRUST IN FINANCIAL TRANSACTION PROVIDERS (School of Business, Society and Engineering). Retrieved from http://www.divaportal.se/smash/get/diva2:1083298/FULLTEX T01.pdf

Bhawika, G. W. (2017). Risiko Dehumanisasi pada Crowdfunding sebagai Akses Pendanaan Berbasis Teknologi di Indonesia. Jurnal Sosial Humaniora, $10(1)$, $47-58$ https://doi.org/http://dx.doi.org/10.12962/j244 33527.v10i1.2355

Cazier, J. A. (2007). A framework and guide for understanding the creation of consumer trust. Journal of International Technology and Information Management, 16(2), 45-58. Retrieved from https://scholarworks.lib.csusb.edu/jitim/vol16/i ss2/4/D8E4D94E73PQ/5 ?accountid=16607

Ennew, C. (2007). Measuring Trust in Retail Banking in China On Behalf of The Financial Services Research Forum. Retrieved from https://www.nottingham.ac.uk/business/busine sscentres/gcbfi/documents/researchreports/pap er57.pdf

Firdayanti, R. (2013). Persepsi Risiko Melakukan ECommerce Dengan Kepercayaan Konsumen Dalam Membeli Produk Fashion Online. Journal of Sosial and Industrial Psychology, 2(1), 64-68. Retrieved from https://journal.unnes.ac.id/sju/index.php/sip/art icle/view/2660

Hamka, A. A., \& Danarti, T. (2010). Eksistensi Bank Thithil Dalam Kegiatan Pasar Tradisional (Studi Kasus Di Pasar Kota Batu). Journal of Indonesian Applied Economics, 4(Mei 2010), 58-70.

Haryani, P., Nugroho, E., \& Adhipta, D. (2015). Pengaruh Dimensi Trust, Keamanan Dan Privasi Terhadap Kepercayaan Pengguna Untuk Layanan Cloud Computing Berbasis Software As Service. Jurnal Teknologi Technoscientia, 8(1), 47-55. Retrieved from https://ojs.amikom.ac.id/index.php/semnastekn omedia/article/view/437/415

Helmi, A. F., \& Arisudana, I. (2009). Kepemimpinan Transformasional, Kepercayaan dan Berbagi Pengetahuan dalam Organisasi. Jurnal Psikologi, 36(2), 95-105. 
https://doi.org/https://doi.org/10.22146/jpsi.78 88

Kazlauskienė, E., \& Bartuševičienė, I. (2013). Trust Dimensions in the Business Relationship. Intellectual Economics, 7(4), 497-509. https://doi.org/10.13165/IE-13-7-4-08

Listyorini, S. (2015). Kepercayaan Konsumen Terhadap Niat Beli Produk Fashion yang Dipasarkan melalui Media Sosial Facebook (Studi pada Mahasiswa S1 FISIP UNDIP Semarang). Jurnal Ilmu Sosial, 14(1), 15-27. https://doi.org/https://doi.org/10.14710/jis.14.1 $.2015 .15-27$

Manzilati, A. (2017). Metodologi Penelitian Kualitatif: Paradigma, Metode dan Aplikasi. Malang: Universitas Brawijaya Press.

Mayer, R. C., Davis, J. H., \& Schoorman, F. D. (1995). Model of Trust. Academy of Management Review, 20(3), 709-734. Retrieved from http://www.jstor.org/stable/258792

Meilianasari, Y. D. (2012). Analisis kepercayaan nasabah pengguna atm. Jurnal Manajemen Bisnis, 2(1), 29-40. https://doi.org/https://doi.org/10.22219/jmbum m.Vol2.No1.\%25p

Moleong, L. J. (2006). Metodologi penelitian kualitatif. Bandung: Remaja Rosdakarya.

Moro, A., \& Kodwani, D. (2012). Trust and the Demand for Personal Collateral in SME Bank Relationships. The Journal of Entrepreneurial Finance, 16(1), 57-79. Retrieved from https://www.uclan.ac.uk/research/explore/grou ps/assets/igfd_trust_and_the_demand_for_pers onal_collateral_in_sme.pdf

Purwanto, F. A. (2017). Pengaruh Dimensi Kepercayaan (Trust) Terhadap Kepercayaan dalam Membeli Barang Secara Online (Studi Kasus Toko Online Bukalapak.com). Jurnal Saintek, 14(1), 1-9. Retrieved from https://www.kopertis7.go.id/uploadjurnal/SAI NTEK Vol 14 No 1 Juni 2017_SIAP CETAK.pdf

Putnam, R. D. (1995). Bowling Alone: America's Declining Social Capital. Journal of Democracy, 6(1), 1-11. Retrieved from https://www.historyofsocialwork.org/1995_Put nam/1995, Putnam, bowling alone.pdf

Rofiq, A. (2007). Pengaruh Dimensi Kepercayaan (Trust) Terhadap Partisipasi Pelanggan ECommerce (Studi Pada Pelanggan ECommerce Di Indonesia) (Universitas Brawijaya). Retrieved from http://ainurrofiq.lecture.ub.ac.id/files/2012/03/t esis_ainurrofiq_dimensi_trust.pdf

Susanti, V., Hadi, C., \& Si, M. (2013). Kepercayaan Konsumen dalam Melakukan Pembelian Gadget secara Online. Psikologi Industri Dan Organisasi, 02(01), 55-33. Retrieved from http://www.journal.unair.ac.id/filerPDF/11091 1101_RINGKASAN.pdf

Syafrini, D. (2014). NELAYAN VS RENTENIR Studi Ketergantungan Nelayan terhadap Rentenir pada Masyarakat Pesisir. Jurnal Ilmu Sosial Mamangan, 1(2), 54-67.

Wahyu Sukmaningsih, D. (2018). A Model for Lender-Borrower Trust in Peer-To-Peer Lending. ComTech: Computer, Mathematics and Engineering Applications, 9(1), 15-24. https://doi.org/10.21512/comtech.v9i1.4287

Waluyani, E. (2010). Studi Tentang Kepercayaan, Hubungan Jangka Panjang, dan Kinerja Outlet (Studi Kasus Outlet Perusahaan Rokok Barito di Jepara). Jurnal Sains Pemasaran Indonesia, IX(2), 166-192. 
https://doi.org/https://doi.org/10.14710/jspi.v9i

$2.166 \% 20-\% 20192$

Wiyani, W., \& Prihantono, E. Y. (2016). Financing for the Poor: Between Formal and Informal Financial Institutions. Journal of Economics and Sustainable Development, 7(6), 59-64. Retrieved from https://iiste.org/Journals/index.php/JEDS/articl e/viewFile/29520/30310

Wong, D. (2017). Pengaruh Ability, Benevolence Dan Integrity Terhadap Trust, Serta Implikasinya Terhadap Partisipasi Pelanggan E-Commerce: Studi Kasus Pada Pelanggan ECommerce Di Ubm. Jurnal Riset Manajemen Dan Bisnis (JRMB) Fakultas Ekonomi UNIAT, 2(2), 155-168. Retrieved from http://jrmb.ejournalfeuniat.net/index.php/JRMB/article/view/46 Yulianto, D. A. (2014). Hubungan Sosial Dalam Transaksi Ekonomi Pada Komunitas Virtual Pecinta Ikan Hias (Study Deskriptif Tentang Proses Pengembangan Kepercayaan Antar Anggota Dalam Proses Transaksi Jual Beli Ikan Hias Pada Komunitas Virtual Pecinta Ikan "O-Fish Forum"). Journal Universitas Airlangga, 3(1), 337-352. Retrieved from http://journal.unair.ac.id/LN@hubungansosial-dalam-transaksi-ekonomi-padakomunitas-virtual-pecinta-ikan-hias-article6552-media-136-category-8.html 